\title{
Promise-Making and the History of Human Rights: Reading Arendt with Danto
}

Emma Stone Mackinnon

Note: Final version to appear in the Summer 2018 issue of Humanity (volume 9, issue 2)

"Dear Mr. President: This is to draw attention to the cases of a group of colleagues of ours, historians well known in the academic community, all of whom are now in prison...Every scholar has a vested interest in this matter. Faithfully, Hannah Arendt"

Letter to Augusto Pinochet, November 27, 1974, writing at the urging of an Amnesty International chapter in Brussels ${ }^{i}$

"Dear Dr. Kissinger: We noted with pleasure the implication in your conversation with Mr. Moyers that you are actively intervening in the release of political prisoners in Chile. We cannot completely agree that public knowledge of the fact would be detrimental in its success - after all

you just have publicized it - and we cannot help but feel that in view of our dismal record in recent times on matters of human rights, a whiff of humanitarianism might earn us friends in the

moral community. But in any case we look forward to news of actual releases in Chile, where our information is that the treatment of prisoners grows daily more horrendous. Yours sincerely,

Arthur C. Danto, Professor of Philosophy, and Ainslie Embree, Professor of History and Associate Dean, School of International Affairs"

Letter to Henry Kissinger, January $24,1975^{\mathrm{ii}}$

In her now classic history of human rights, Lynn Hunt describes what she calls the "promise" of the rights of man, a promise which, she claims, "can be denied, suppressed, or just remain unfulfilled, but...does not die."iii While her critics rightly take issue with her claim that rights have a "logic," their fulfillment a certain inevitability, they themselves also make use of the language of promise-making, accepting Hunt's description of Enlightenment rights commitments but disputing whether later moments are in fact making claims, in a conceptually coherent way, against those particular earlier promises. Even Hunt's most vocal detractor, Samuel Moyn, refers to the "broken promises" of human rights, arguing that anticolonial movements should not be considered part of the history of human rights because they opted to draw not on that promise, but on a different one: that of collective liberation. He agrees with 
Hunt that universal promises are open to claims for fulfillment; he differs from her in thinking that such claims are inevitable, emphasizing that later actors have more agency than her account suggests. He writes: "The case of the decolonizing world shows clearly that not all universalistic promises spark seizures from below of their unrealized potential. ${ }^{\text {,iv }}$

Behind the Hunt-Moyn debate is not just a disagreement about continuity or discontinuity, long versus short history, but a question of how promises enable or foreclose later forms of claim-making, how promises operate in time to open or shut off spaces of political possibility. Posed this way, the issue appears as one not just of history, but of political theory. Along these lines, I propose we re-approach the question of how later claims relate to earlier promises by reconsidering the category of the "promise" itself. Rather than think about promises in terms of their initial truncation and later extension, or their non-fulfillment followed by "seizure from below," we might think of one promise following on another, as a repeated practice in which later promises revise aspects of what came before. This provides an alternative to viewing later moments as either claims against previous ones, attempts at augmentation or fulfillment, or as wholly separate and discontinuous with that past. Instead, new promises seek to recast the past, altering its legacies so as to project new futures.

To theorize the "promise," I make use of Arendt's classic discussion of "promise making" as a political practice, and its relationship to the uncertainty of action, in The Human Condition. ${ }^{\vee}$ I understand "promise" here as an attempt to make a space of appearance endure in time, to project a possible future amid uncertainty. To develop this, I read Arendt's account of promise-making together with Arthur Danto's discussion of the philosophy of history, and in particular what he terms "narrative sentences," in order to emphasize the uncertainty not just of the future, but of the past, and the ways in which political actors might revise the past itself, and 
so alter its legacies. My reading allows us to better understand what Arendt means about the "uncertainties" of action against which promising secures us: I propose that this uncertainty is not just a matter of unforeseen consequences; what's more, it is not just uncertainty about the future. It is also uncertainty about the past: about how the past will matter for the present and for the future. In making promises, political actors narrate the past in order to contest its meaning for their present, to project possibilities for the future, and so to render certain futures possible. Promises reference and narrate the past not because it is fixed, but because it isn't; in this way, promises manifest freedom.

This has implications for how we, as theorists and historians, narrate the history of human rights, and what sort of future we project when we do so. Approaching human rights in the way I propose offers a way of narrating the history of human rights that avoids both romanticism and reduction. We can think of Hunt as telling a particularly romantic version of human rights history, figuring the redemption of human rights promises as not only possible but inevitable. ${ }^{\mathrm{vi}}$ Moyn's account, in contrast, is so relentlessly realistic that it risks being reductive, risks missing the political potential present in certain promises. In considering anticolonial movements, Moyn claims that actors chose between two alternative conceptual traditions - as though these were fixed, and as though their nonfulfillment was somehow incidental to the ideals themselves. He neglects the alternative possibilities present in those movements, possibilities both for alternative futures and for alternative pasts. Responding to concerns about the very possibility of fulfillment, about the ways in which promises themselves have been bound up, conceptually and historically, with their own nonfulfillment, actors sought not merely to fulfill but to alter conceptual legacies, to change the past and so initiate new projects. Similarly, looking to the 1970s, Moyn identifies a moment in which new ideas of human rights appeared, only to reduce those ideas to what their 
political ramifications ultimately were, rather than consider what they could have been - what other possible futures those ideas contained, and what other versions of the past. While this may not make for bad history, it misses something important about politics. ${ }^{\text {vii }}$ In contrast, treating promises as political acts in which people attempt to narrate their own history and future, without any guarantees of fixity, allows us to consider the ways in which various moments in human rights history relate to each other, while emphasizing openness and uncertainty.

To demonstrate and expand on this, I turn in the second half of the paper to the version of human rights politics that Moyn diagnoses as coming to prominence in the 1970s, and that he associates in particular with Amnesty International - a human rights politics in which Danto himself participated, as did, more peripherally, Arendt. I draw on archival research to reconstruct Danto's role in Amnesty, his political commitments, and the intersection of his politics with his philosophy. Here, I hope to further develop the concept of promise-making, and the way it appears in history not as an unfolding of the logic of human rights, or a spread of enlightenment principles, but rather as a highly contingent and contested process that involves acknowledgment but also often disavowal, the emergence of spaces of appearance as well as their closure. Where historians often use Amnesty as proof of the bankruptcy of contemporary human rights politics, my understand of human rights history offers us a way to view this moment for what was valuable in it - without either reducing it to what came after or treating it as an extension of what came before. I argue that, for some of those involved, it may in fact have involved a kind of human rights promise-making, one directed empire and triumphal narratives of progress directed, that is, against the very disavowals of history and politics that, its critics charge, it nonetheless ultimately enabled. 


\section{Part I: Arendt, Danto, and the Politics of Promises}

\section{A. Re-Founding Narratives of the History of Human Rights}

Perhaps the most straightforward version of the history of human rights begins from promises of human rights in the French and American declarations, and then tells a story of those promises' gradual fulfillment. While not initially fulfilled, the story goes, the fact of these promises allowed those denied rights, or denied recognition of rights, grounds on which to make rights claims. On Lynn Hunt's account, the abstraction of the initial promises, combined with the rise in practices of empathy, made rights vulnerable to claiming from below.

Hunt seems to take this a bit far in places, as Moyn has criticized, suggesting that rights have an "internal logic" that rolls out like a "bulldozer." viii At the same time, even Moyn agrees that if we drop the notion of a kind of destiny or teleology to universalist notions of rights, we can still see that "in the revolutionary era, universalistic concepts had 'cascade' effects as unintended actors claimed them"; that the abstraction inherent in notions of universal rights allowed people to make claims, and granted those claims a certain strategic value. And, as discussed above, in the moments which Moyn claims are not in fact moments of true human rights movements, his argument is often that they are not moments where fulfillment is being demanded, again implying a promise-and-fulfillment model. ${ }^{\text {ix }}$

There are reasons to be uncomfortable with this narrative of human rights history. One has to do with the view it provides of those early, foundational promises. While both Hunt and Moyn underscore the non-inclusiveness of the American Declaration, they also treat its exclusions as a separate issue from its universalist principles. Doing this misses the ways in which the Declaration's ideals and words were themselves tied up with various forms of exclusion. More importantly, it also fails to give later claims their due, taking them to be 
pointing out hypocrisy, decrying a failure to live up to stated principles, rather than revising and reformulating those core principles themselves.

Just how abstract and open the Declaration's principles were is, at the very least, subject to debate. Other scholars have emphasized the ways in which nonfulfillment can in fact be understood as intrinsic to the Declaration's principles themselves. Perhaps most notably, Aziz Rana argues that the Declaration should be understood as a defense of settler colonialism. The Declaration was provoked, on his account, by a changing British view of American colonists, and a growing tendency to treat them not as citizen settlers, but as themselves colonial subjects. On this reading, the Declaration was in fact a defense not of abstract universal freedom, but of an earlier model of colonialism. The notion of freedom it enshrined was very particular: that of a land-owning homesteader. Realizing such freedom, Rana argues, necessarily relied on forms of internal and external colonization. If this is so, the openness and abstraction of the Declaration's principles cannot simply be taken for granted, and any politics of "claim-making" would require close scrutiny to the ways in which those principles might be caught up with forms of exclusion and domination. ${ }^{\mathrm{x}}$

One does not have to view the ideals of the Declaration as inherently exclusionary, however, to question their availability as a basis for appeal. This is evident in the role of the Declaration's principles in African American political thought, where questions about the nature of the hypocrisy involved in their non-fulfillment are particularly central and complex. Related to the question of whether the Declaration's principles themselves enabled, or even required, forms of domination is the question of whether those ideals were truly held and believed by white Americans, but simply not enacted, or whether they were never believed at all, but merely pronounced. Robert Gooding-Williams describes this as a central fault line among those who 
seek to formulate a politics to counter white supremacy, dividing, in particular, W.E.B. DuBois from Frederick Douglass. Drawing on Douglass's speech "What to the Slave is the Fourth of July," Gooding-Williams argues that Douglass considers non-fulfillment a problem of "hypocrisy" - understood as a conflict between what was said and what was in fact believed. On Gooding-Williams' reading, Douglass viewed American founding promises as having been sincerely held by their original authors, but claimed that the white "sons" did not take them up, did not in fact believe in those principles. Gooding-Williams associates the alternative account of hypocrisy, what he terms the "anomaly" version, with DuBois; on this view, the problem is not insincerity of belief, but a conflict between belief and action, principle and practice. The choice between these two views, of course, has major consequences for what sort of politics one thinks is necessary, what sorts of claims can and should be made. ${ }^{\mathrm{xi}}$

Along similar lines, Paul Gilroy describes what he terms the "politics of fulfillment" as a red thread running through African American political thought from Alexander Crummel forward, focused on the question of the possibility of the fulfillment of foundational American promises. This is, he argues, the question that in fact underlies the debate about separatism versus assimilation, though it rarely yields a straightforward answer. ${ }^{\text {iii }}$ To reduce the politics of fulfillment to simply a demand that promises be fulfilled would be overly reductive; to reduce it to a demand for self-determination would mean missing its animating tensions.

Gooding-Williams describes Douglass's approach as a politics of "re-founding," a politics compatible with the view that white Americans do not truly subscribe to their proclaimed ideals, that the principles themselves must be renewed through a kind of "moral transformation." ${ }^{\prime x i i i ~ G o o d i n g-W i l l i a m s ~ r e a d s, ~ i n ~ D o u g l a s s, ~ s e v e r a l ~ m o m e n t s ~ i n ~ w h i c h ~ h e ~ e n a c t e d ~}$ his own "declarations of independence"; in the language of this paper, we might say that 
Douglass was engaged in his own practice of promising-making. Such promises are not necessarily either separatist or assimilationist. Rather, they initiate new projects precisely by offering new narratives of the past, and so continue to change the significance of that past as it persists in the present. In this sense, projects of re-founding are compatible with a view that sees certain past promises as intrinsically caught up with their own apparent nonfulfillment, a view that understands how America's foundational ideals have also enabled slavery and racial domination. This should not mark them as either appeals for fulfillment, or as separate from and outside the history of those earlier promises.

Forms of narration and re-founding, contests over how to narrate the past, are not unique to those seeking to resist its exclusions. In the mid-twentieth century, such efforts at narrative are evident both in the mainstream version of human rights politics epitomized by the Four Freedoms speech and the writing of the Universal Declaration of Human Rights, and in more radical human rights politics, particularly politics directed against white supremacy and colonialism (the moments Moyn describes as involving not human rights but self-determination). Mary Ann Glendon summarizes this, and in a sense performs it, when she writes: “The Declaration [UDHR] marked a new chapter in a history that began with the great charters of humanity's first rights moment in the seventeenth and eighteenth centuries. The British Bill of Rights of 1689, the US Declaration of Independence of 1776, and the French Declaration of the Rights of Man and Citizen of $1789 \ldots$ gave rise to the modern language of rights." ${ }^{\text {"xiv }}$ Presiding over the 1948 meeting of the UN General Assembly at which the Universal Declaration of Human Rights was adopted, in Paris, René Cassin invoked 1789 and the Declaration of the Rights of Man and Citizen, and "the long struggle for the rights of man" (le long combat pour les droits de l'homme) of which the meeting was, he claimed, only the latest stage. ${ }^{\mathrm{xv}}$ At the same 
time, in the opening chapter of the NAACP's 1947 petition "An Appeal to the World: A Statement on the Denial of Human Rights to Minorities in the Case of Citizens of Negro Descent in the United States of America and an Appeal to the United Nations for Redress," which had been submitted to the drafting committee of the UDHR, DuBois cites "the high and noble words" of America, "a nation which boldly declared 'That all men are created equal,"” and which, he went on to argue, was failing to live up to those core promises. ${ }^{\text {xvi }}$ We see, on both sides, attempts to narrate the past, to describe and influence its meaning, in order to project a particular future.

The period from the late 1940s to the early 1960s involved many moments of founding and re-founding, especially as decolonization proceeded. Actors in this period did not simply choose between a language of human rights and a language of self-determination; rather, the question of self-determination was intimately tied up with questions of the possibilities of fulfillment. This is illustrated, for instance, in recent work on federationism. Gary Wilder provides an account of the idea of a federation to follow the French empire in the work of Aimé Césaire and Léopold Sédar Senghor. Senghor, on Wilder’s telling, proposed neither an incorporation of Senegal into France, nor separation from France entirely, but rather that "by taking literally the constitution's language about the Fourth Republic as a union of peoples," they might achieve "a type of integration that would reconstitute France itself." "xvii Such claims are not properly understood as claims for fulfillment. Rather, they were themselves moments of promise-making, marking out spaces of appearance in a sea of uncertainty about both the relevance of the past and prospects for the future. Viewed as such, we can understand them not as augmenting past political projects, but as initiating their own, and thereby altering the significance and meaning of past promises in the present. To elaborate what it means to understand these as moments of promise-making, and to get clear on how promises in particular, 
as opposed to contests over historical legacies in general, might in fact change the past and secure possibilities for the future, I turn here to Arendt's discussion of promise-making, and to Danto's discussions of history.

\section{B. Reading Arendt on Action and its Frustrations}

Contemporary political theorists have made use of Arendt's account of action, and her related account of power, to describe a practice of politics that is ongoing and agonistic, not oriented toward rule but rather based in an understanding of non-sovereignty, including an ontological rejection of the idea of a sovereign rights-bearing subject. ${ }^{\text {xviii }}$ In turning to Arendt to understand promise-making, I share many of these motivations, though I want to develop a reading that is more attentive to the temporal aspect of action as she describes it, and so more attentive to how action endures in time. This reading offers, I claim, a more robust account of what Arendt means about the "uncertainties" of action, and unites an understanding of promises with an understanding of how we narrate their histories.

For Arendt, action is a central category of what she terms the vita activa. It is differentiated from the other two categories, labor and work, as "the only activity that goes on directly between men without the intermediary of things or matter.” Action, she continues, "corresponds to the human condition of plurality, to the fact that men, not Man, live on the earth and inhabit the world."xix Action's definition is grounded in the claim that there are beings, not Being, that existence is always plural. It is this condition of plurality that provides the possibility of politics. 
Plurality, on Arendt's account, involves both equality and distinctiveness, and as a result, action is premised both on an act of disclosure that brings forth something new, and on an equality that makes that disclosure possible. Equality, she continues, allows people to understand each other and anticipate each other's needs and wants across historical time; distinctiveness, however, means that such understanding is not automatic, that action and speech are required. Here, action and speech are more than "signs and sounds": they transmit not only "immediate, identical needs and wants," but something more. Action and speech involve one's particular ability to initiate, to begin something new. Such beginning is something we do purely on our own initiative; it is not, she claims, something, like labor or work, that we have to do out of necessity or concerns about utility. ${ }^{\mathrm{xx}}$ Uniqueness is tied in this way to natality; taking initiative, starting something new, is, on Arendt's description, a "response" to the fact of birth.

When writing about Arendt's account of action, many readers focus on the "threefold frustration of action" she describes, reading it as part of her broader claims about nonsovereignty. I want to return to the passages in which Arendt discusses action's frustration, while attending closely to the temporal aspects of action and of uncertainty. My worry is that some contemporary readings interpret action's frustration as some version of a 'law of unintended consequences,' and so miss or mischaracterize an important part of the argument: her point about action's temporality. This matters for Arendt's understanding of promising, which, on my reading, secures us against action's frustration by creating a "space of appearance," to use her term, that persists in time.

Arendt's central explanation of action's frustration contains the first clue that action's frustration has something to do with time, and with the telling of history. She writes: "Exasperation with the threefold frustration of action - the unpredictability of its outcome, the 
irreversibility of the process, and the anonymity of its authors - is almost as old as recorded history."xxi This can easily be read, especially given the invocation of "unpredictability," as an argument about how action can have ramifications not intended by the actor, and so elude control. Amy Allen seems to tell such a story when she explicates the frustration of action in this way: "action in the public, political realm['s]...outcome is unpredictable, so it tends to produce unintended effects; as a result of this, once an action has been initiated, it is irreversible; and, as a result of these first two characteristics, the author of an action is often unknown." ${ }^{\text {xxii }}$ While not incorrect, this doesn't capture the depth of Arendt's claim, and in particular does not describe what makes this frustration unique to action. It also doesn't capture the threefold nature of the frustration, but instead prioritizes the unpredictability of the outcome, treating irreversibility and the anonymity of the author as consequences thereof. Arendt is not simply saying that the world is complex and unpredictable, that the implications of our actions often exceed our intent - that much could be said for the implications of our work or labor as well. Action's frustration goes to the core of what action is: that it brings forth something new, that it reveals us as unique and equal beings.

It is this revelation of the actor that brings out the dual passivity and activity, nonsovereignty coupled with agency, at the core of Arendt's understanding of action. Arendt writes:

This revelatory quality of speech and action comes to the fore where people are with others and neither for nor against them — that is, in sheer human togetherness. Although nobody knows whom he reveals when he discloses himself in deed or word, he must be willing to risk the disclosure, and this neither the doer of good works, who must be 
without self and preserve complete anonymity, nor the criminal, who must hide himself from others, can take upon themselves. ${ }^{\text {xiii }}$

Both good works and criminal acts involve unintended consequences, but neither, it would seem, qualifies as action. Action, and the threefold frustration that characterizes it, instead has to do with being with others, a condition in which it is not simply something about other people's intents that might elude us, but something about ourselves, something about what we would expose when we disclose ourselves, through action, to others. Action involves revealing or disclosing oneself, a disclosure that exceeds our capacities for knowledge and control.

Bonnie Honig, in her Political Theory and the Displacement of Politics, describes action's frustration in terms that risk sounding similar to Allen's. After describing promising and forgiving as establishing "partial" areas of stability in which "lasting political communities" might be formed, as "promising binds some to others, in time, and forgiving empowers those bonds to survive," Honig worries that these communities would be endangered by the contingency of the world and of action in it. If promising, like all action, is "terribly risky because it takes place in a contingent world where its meaning and consequences are always underdetermined if not indeterminate," how can promising also secure against such risks? She sets this up as a kind of dilemma: either promising can create stability, because action is not "as risky, as contingent and unpredictable, as Arendt says it is," or action is in fact contingent and risky, and promising could not secure us against this. Honig points to this as a central paradox for Arendt, one that is constitutive and in some sense irresolvable. ${ }^{\text {xiv }}$

Others look at this alleged paradox and instead see contradiction. In Democracy in Question, Alan Keenan describes Arendt's account as “caught between freedom and 
foundation," arguing that promising "oscillates essentially between these two poles." His concern is that, for promising to provide security, it must be "foundational," and so limit later "free" acts because they are bound by that security. He writes: "Promising can effectively lay down the law of freedom only by immediately violating that same law: it is a free act that at once makes less than fully free all acts that follow its law and example." For promising to secure us against uncertainty, it would also secure us against our own freedom, a freedom that arises precisely from non-sovereignty. ${ }^{\mathrm{xxv}}$

Behind both Keenan's and Honig's views is an understanding of the future as uncertain and contingent, and the past as fixed and stable. But what if, rather than view the past as fixed and the future as uncertain, we treat history itself as uncertain? The freedom of action has to do not just with the future, but with the way the significance of action unfolds over time. This is a more radical reading of Arendt as a philosopher of history: her claim goes beyond the idea that the future isn't yet known, questioning the very notion of historical knowledge and the fixity of past action.

To develop this, we might read Arendt together with Arthur Danto on the philosophy of history; here, I have in mind Danto's argument that history is not simply a chronicle of past events, but a story about significance. Describing what he terms "narrative sentences," Danto suggests that the past is not as fixed as we commonly take it to be, the future perhaps not as plastic. Narrating history requires not only knowledge of the past, but knowledge of the future, without which we cannot have a sense of beginnings and endings and so cannot have stories. ${ }^{\text {xxi }}$ Yet in the present, we have no such knowledge of the future. Acting in the present, then, means directing oneself toward a future that is unknown, and so not knowing the significance of what one does, what story one is engaged in. Danto's claim thus goes beyond the idea that we do we 
not know the future, arguing that we also do not know the past, or even the present. In the terms Arendt used, we might consider the "exasperation" that is "as old as recorded history" to be an exasperation with the task of writing narrative sentences, with describing a past as though it is fixed when in fact it is anything but, with attempting to adjudicate beginnings and endings. It is as old as recorded history because it concerns the recording of history. ${ }^{\text {xxvii }}$

So does a promise, in announcing a beginning and attempting to secure a future, limit future acts? Does it, in Keenan's terms, lay down the law? I take Arendt, read with Danto, to be saying something different. Making a promise can be understood as a "founding" only later; at the time, it may assert a beginning and initiate a space of appearance, but the significance of that foundation, even its status as foundation, is constituted only in retrospect. When later promises make reference to moments of foundation and make claims about their significance, they are not in this way bound by that past, but are in fact exercising freedom over it. For moments of foundation to succeed, and so to have some purchase on the future, we have to read the past in a particular way, to participate in that past action and in the ongoing determination of its significance. Meaning and significance is not contained in what might retrospectively be viewed as the moment of beginning, but is part of how that action unfolds over time. Foundations are not moments of fixity, against which future claims can be made; rather, the meaning of those foundations is itself still unfolding. ${ }^{\text {xxviii }}$

For Arendt, the issue is not just that action can only come to be known after the fact, but that action itself continues beyond the moment of any single deed. Action endures and extends across time. She writes: 
The strength of the action process is never exhausted in a single deed but, on the contrary, can grow while its consequences multiply; what endures in the realm of human affairs are these processes, and their endurance is as unlimited, as independent of the perishability of material and the mortality of men as the endurance of humanity itself. The reason why we are never able to foretell with certainty the outcome and end of any action is simply that action has no end. The process of a single deed can quite literally endure throughout time until mankind itself has come to an end..$^{x i x}$

Action is potentially unending, not circumscribed to a moment or to the durability of a thing or even a life. Its unpredictability, irreversibility, and anonymity are the result of this temporal character.

Action's unpredictability, then, is not simply a matter of an inability to accurately model all possible outcomes, but instead refers to the fact that the meaning of actions is not contained in a single moment. As Arendt puts it, "This is not simply a question of inability to foretell all the logical consequences of a particular act, in which case an electronic computer would be able to foretell the future. ${ }^{\prime \times x x}$ Danto also rejects the idea of simply correcting an account of the past based on later unforeseen outcomes, which he writes "is just the sort of thing a machine could do," but is not in fact the task of the historian. ${ }^{\text {xxi }}$ Instead, Arendt writes that "the light that illuminates processes of action, and therefore all historical processes, appears only at their end" and that "action reveals itself fully only to the storyteller." xxxii This story, the meaning that action reveals, is part of action itself, part of what it discloses, and yet comes after the deed.

Arendt's storyteller and Danto's historian call to mind Hegel's Owl of Minerva, flying only at dusk. For Danto, Hegel's claim holds what he calls a "melancholy truth." 
aphorism tells us about the impossibility of knowing one's own present - that "to live in a period is not necessarily to be in a favored position for appreciating the quality of life that defines it." He likens this to the phenomenon of "Other Minds," writing that, as with minds, "there is no privileged access to the interior of a period on the part of those whose period it is," because "access to the interiors of periods is achieved not by some sort of reflex act...but refracted back through the knowledge of other periods." ${ }^{\text {xxiv }}$ Yet this also makes the experience of living in a certain period incomprehensible to those in the future, because "not knowing how it is all going to end is the mark of living through events. ${ }^{{ }^{\prime} \times x x}$ In this way, other periods might really be other. And in this sense, contra Verstehen approaches to history, which aim to fully understand a period as it was experienced, Danto claims that the task of the historian is to tell a story. ${ }^{\mathrm{xxvi}}$

In some general sense, of course, we cannot change the past - as Danto writes, "For some centuries there has been no opportunity to morally re-educate the Borgias so as to make the statement 'The Borgias were decent folk' come out true." And yet, he claims, "there is a sense in which we may speak of the Past as changing...because the event at [time] 1 comes to stand in different relationships to events that occur later." ${ }^{\text {xxxvii }}$ To say, following one of Danto's favorite examples of a narrative sentence, "The Thirty Years War began in 1618," does not describe the experience of 1618 , but rather tells a story. Such sentences stand as "descriptions under which the events of which they are true could not have been observed."xxxviii

For Arendt as well, this is not a radical skepticism about the possibility of historical truth, but rather a question of how we come to know that truth, how we make sense of it. On her account, as she elaborates in her essay "Truth and Politics," there are certain aspects of the past that are given, that are true, and that cannot and should not be reshaped by ideology. The task of the historian is not to create reality, but to reconcile us to it; this makes history distinct from 
ideology. And yet the story of which the past is part is not something that inheres in that moment; it is visible only later, to the storyteller. ${ }^{\mathrm{xxxix}}$

\section{Forgiving and Promising}

I want to return to what Arendt means by promising and forgiving, and their relation to the uncertainty of action, to get clear on what it is that is distinctive about promises in particular. Forgiving, which is retrospective, and promising, which is prospective, provide security against the uncertainties of action past or future, allowing action to endure in time. Forgiving and promising are part of Arendt's answer to the question she poses of "whether the capacity for action does not harbor within itself certain potentialities which enable it to survive the disabilities of non-sovereignty." ${ }^{\text {’l }}$ She attributes to forgiving and promising the ability to preserve the potential for action: by allowing action to survive its own frustrations, and by allowing people to stay together even without physical proximity, they make action possible.

Arendt presents forgiving and promising explicitly as faculties that counteract the frustrations of action and preserve the relationships between people. She writes:

The possible redemption from the predicament of irreversibility $—$ of being unable to undo what one has done though one did not, and could not, have known what he was doing — is the faculty of forgiving. The remedy for unpredictability, for the chaotic uncertainty of the future, is contained in the faculty to make and keep promises. The two faculties belong together in so far as one of them, forgiving, serves to undo the deeds of the past, whose 'sins' hang like Damocles' sword over every new generation; and the other, binding oneself through promises, serves to set up in the ocean of uncertainty, 
which the future is by definition, islands of security without which not even continuity, let alone durability of any kind, would be possible in the relationships between men. ${ }^{x l i}$

But what does it mean that forgiving actually undoes the deeds of the past? This claim makes sense only given a very particular understanding of what constitutes a deed. If we think of action in the usual way, it would seem one could forgive but not in fact undo (hence the logic of “forgiving but not forgetting") - particularly given what she told us earlier about action's 'irreversibility.' We would expect that forgiving might absolve us of guilt, or allow us to account for past missteps, but not in fact take back the action itself.

But if we conceive of action as revealing us as people, if we think of it as how we appear in the public realm, then forgiving would have more purchase. It might even, as Arendt claims, be able to undo a past act - in that it could undo, or at least alter, an aspect of our appearance. Put another way, if we think of action not as confined to a moment in time, but as extending forward, beyond even the lifetime of the doer - if, that is, we think of it as Arendt thinks of it then forgiving certainly can undo an action, precisely by revising it. xlii After all, that action is not entirely in the past, but exists in the present and future as well. As Danto suggests, perhaps the past is more plastic than we generally take it to be.

Similarly, where forgiving counteracts irreversibility, Arendt claims that promising counteracts uncertainty. Making and keeping promises appear as a single faculty, one that allows for continuity in the relationships among people. Promising carves out durability in our relations with one another, allows us to project a current set of relationships, or space of appearance, into the future. To pick up on an earlier theme, we can add that the very fact of the preservation of such a space - or the possibility for preservation - is itself what constitutes the promise. This has 
more to do with a relationship among people than with the utterance of a particular phrase. The initial promissory statement (if there is such a statement) does not in itself constitute the "promise" any more than the enunciation of wedding vows might be said to, on its own, constitute a "marriage" (to use a classic example of performative statements involving promising). In both cases, what is at stake is an ongoing relationship between people, a way of showing up for one another. ${ }^{x \text { liii }}$ Ideally, this does not limit one's freedom in the future, but instead makes one more free.

Forgiving and promising are so profoundly intersubjective for Arendt that she claims contrary to our everyday, common language usage - that one can only forgive or make promises to another, and not to oneself. She writes:

Without being bound to the fulfilment of promises, we would never be able to keep our identities; we would be condemned to wander helplessly and without direction in the darkness of each man's lonely heart, caught in its contradictions and equivocalities - a darkness which only the light shed over the public realm through the presence of others, who confirm the identity between the one who promises and the one who fulfils, can dispel. Both faculties, therefore, depend on plurality, on the presence and acting of others, for no one can forgive himself and no one can feel bound by a promise made only to himself; forgiving and promising enacted in solitude or isolation remain without reality and can signify no more than a role played before one's self. ${ }^{\text {xliv }}$

Promising, by making us visible to each other, makes us visible also to ourselves: it binds our current selves to our future selves, creating continuity in our identities. Strikingly, this continuity 
is not visible, not illuminated - even to ourselves - absent the ability to make and keep promises. Without the faculty of promising, we would be left with contradictions and equivocalities in our very sense of who we are, discontinuities in our understanding of our own identities. Promising and forgiving secure a space of appearance among people that runs across time.

In his book Omens of Adversity, on the legacies of the Grenada Revolution, David Scott also picks up on the role of forgiving and promising, and particularly forgiving, in relationship to the uncertainties of action that Arendt describes. Scott's book is helpful for its description of the way in which changing one's present relationship to a past tragedy, a failed revolution, might change the possibilities for action. On his telling, in October 1983, the Grenada revolution "self destructed": Maurice Bishop and other leaders of the popular revolutionary government were assassinated, replaced by military rule; the US invaded several days later. The lack of clarity about what happened to Bishop and the others, and in particular the fact that, after the US invasion, 18 former members of the government and military were charged with the killing, and yet the bodies were never found, "ruined a generation's experience of time- that is, it destroyed the temporality constitutive of the organization of political hope and future-oriented expectation through which a generation lived." The dashed promise of the revolution made action in the present impossible. A notion of time as progressive, involving successive dialectical overcomings, instead gave way to melancholic repetition of loss, "an ending that could not be brought to an end."’xlv

In places, Scott can seem to reduce action's frustration to a problem of unintended consequences. He explains his concern, in the first chapter of the book, with "the unintended tragic consequences of moral agents acting, and colliding, in an expressly political field"; he continues: "For Arendt, to act politically in time (which for her is to act disclosively and in 
freedom) is unavoidably to expose oneself to the potential collision of actions embodying rival ends, competing interests." ${ }^{\text {"xlvi }}$ But I read Arendt in The Human Condition to be arguing that it is action's disclosive character, its very temporality and the stories we tell - and not the collision of different actions, or rival interests, as Scott puts it - that renders action uncertain, and, on his terms, tragic. This is a reading in fact, I think, more compatible with Scott's broader point, in this book as well as his earlier Conscripts of Modernity, about the plasticity of the past and the role of the storyteller in introducing genre, plot, and meaning. ${ }^{\text {xlvii }}$ Indeed, in his example of Grenada, it is a re-narration of the past, through an act of forgiveness, that allows for a greater sense of possibility for action in the future. The perils related to the uncertainty of action arise not from the fact that other people might have other intentions, that other actions might get in our way: they arise from an uncertainty about the stories of which we are part, and the fact that action exists in time, as part of a story. It is not greater coordination that is required, an attempt to better align one's intentions with those of others. Promising and forgiving appear not as means of aligning interests and intents, but as ways of attaching action to ideas of past and future, of projecting a story.

Indeed, Scott, following Arendt, points to forgiveness as one mode for enabling action (even while, remembering Honig, it is also itself a kind of action), because it might alter this melancholic sense of time. Using the example of a booklet produced by secondary school students, Under the Cover of Darkness, which investigated what had happened to those bodies, he describes such historical investigation as itself a "performative act." It is performative, he claims, because "it shows that the present can live with the past—even the not entirely resolved or resolvable past-in ways other than melancholia and in ways that potentially open the present to ethical-political intervention." ${ }^{\text {"xlviii }}$ By re-narrating history, changing the meaning of the past 
for the present through a kind of forgiveness, it enabled ongoing action in the present, creating precisely that "future-oriented expectation" that had, on Scott's account, been lost.

Promising and forgiving structure our understandings of temporality in the present, and so can change our notions of emplotment. In this way, they change the way we live with the past and the future, and thus change the prospects for action. More than just re-narrating the past, contesting legacies, they bind a particular articulation of historical legacies to a shared commitment to the future. They establish relations among people, through a pledge to show up for one other, that is premised on a particular version of the past and generates particular possibilities for action going forward. It is no surprise, then, that the term is used so often to describe foundational rights declarations, the creation of a polity through an act of mutual recognition.

\section{PART II: Amnesty International and the Uncertainties of Political Meaning}

\section{A. The Historians' Consensus on Amnesty International}

I want to jump forward a bit, to the version of human rights ascendant in the 1970s, a version that displaced the more radical political aspirations of the 1940s to 1960 s. This was a time when human rights discourse captured much of the public imagination. Where the earlier declarations have been praised for the alleged openness implicit in their abstract notion of humanity, in this later case that very openness is often criticized by historians for involving its own forms of closure, and for displaying an idealism that distracted from both history and politics. On this account, the 1970s represents the beginning of a new and less avowedly political version of human rights. Amnesty International, an organization based in London with a network of affiliated "chapters" throughout the world, is often singled out as exemplary of this new kind 
of human rights politics. And yet, I want to show, within the politics surrounding Amnesty International we can also see some elements of a different, and potentially more political, form of promise-making.

Turning to this period also lets us approach Arthur Danto's work from another angle: his own involvement in Amnesty. Danto's profoundly anti-teleological and anti-positivist understanding of history is underscored by this involvement, as well as by his broader political engagement from the 1960 s forward. ${ }^{x \text { lix }}$ Looking to his political practice allows us to see more of what he describes as the openness, or uncertainty, of action. By offering a more nuanced view of Amnesty, an aspect of Amnesty that was more avowedly political, more critical of historical injustice, it also allows us to avoid writing Amnesty off as inaugurating a "bad" version of human rights politics, and instead attend to what its promise was, as well as to where it fell short. In this way, we might re-narrate human rights' recent history, seeing it now in a manner that is less reductive, and more attentive to the forms of freedom implicit in human rights politics.

The organization was created to help free what it termed "prisoners of conscience" around the world - that is, prisoners who had been arrested for political activism, with the caveat that they had not advocated violence. Amnesty chapters would "adopt" prisoners, generally assigned to them by the London office. Having adopted a prisoner, a group would send letters to members of the prisoner's government, as well as, frequently, to the prisoner directly. They also sought to publicize the cases in news media, drawing attention not only to the fact of imprisonment, but to the forms of torture and coercion used against prisoners. Amnesty produced reports on human rights abuses in particular countries, which did not focus on individual prisoners but on broader patterns of maltreatment. Amnesty also, importantly and somewhat controversially, prohibited chapters in any country from adopting prisoners in their own country. 
The organization measured its success in terms of prisoners released, and defined its goal as the release of all prisoners of conscience and the fulfillment of the Universal Declaration of Human Rights. ${ }^{1}$

For historians who point to Amnesty as marking the beginning of a new kind of human rights politics, the central charge is that Amnesty International depoliticized human rights. Human rights were posited as a pre-political ideal; their fulfillment, the protection of abstract humanity, as the end of politics. In The Last Utopia, Samuel Moyn describes Amnesty International as inaugurating a new kind of human rights politics; as he puts it: "in the face of soiled utopias in politics, a nonpartisan morality existed outside and above them," a utopian vision, with religious roots, that supplanted the more radical visions of political change of the 1960s. ${ }^{\text {li }}$ Barbara Keys reaches a similar assessment of Amnesty International, writing:

Though Amnesty International's achievements are impossible to measure precisely, the organization undoubtedly helped thousands of prisoners, giving them hope, reducing the terms of their imprisonment, and providing relief to their families.... On a grander scale its efforts inspired the world to hold governments accountable for some of the most horrifying state-sponsored abuse of individuals. But its efforts inevitably involved political trade-offs. Amnesty treated political problems as moral ones, thereby eliding the deeper political changes that social justice often required. Focusing on 'mere' protection of individuals from 'fundamental wrongs' ...worked to push politics, as a project of collective empowerment, to the sidelines. ${ }^{\text {lii }}$ 
Amnesty's defense of a pre-political morality, that is, displaced the politics of collective action and a broader agenda for justice. As Mark Bradley tells it, Amnesty's emphasis on "the singularity of the person and the body," its reliance on a language and practice of moral witness and testimony, and what he calls "a perpetual concern with performing its own impartiality," helped define its legacy in the generation of a particular American human rights vernacular - one characterized by "a conscious indifference to the political and social contexts that produced human rights violations in the first place." "liii On Keys' telling, this fit all too well with the broader Cold War politics of the time, allowing Americans an ideal of humanity, associated with their supposed founding principles, that distinguished them from the Soviets while also obscuring their own involvement in forms of racial and imperial domination, in part by supplanting the memory of Vietnam. Oriented around an allegedly apolitical moral category, it abstracted away from the very politics within which it intervened.

It is tempting, following these historical accounts, to point to the 1970s moment as a beginning, as the start of a period in which human rights politics took a turn for the worse precisely as it captured a broader public imagination. Yet as Bradley emphasizes, the rise of the "human rights movement" in the 1970s did not mark something new, but instead the travel and blending of different languages for politics. To view it as the start of something, an origin of our contemporary human rights politics, would be to miss much of what characterized the experience of the time: an uncertainty about possibilities for action. This uncertainty comes to the fore when we focus on what might have been valuable in Amnesty's work, the parts that were directed against the very depoliticization the historians describe. Viewed through Danto's involvement, we can see moments in which the kind of activism that comprised Amnesty's work could also involve a critical stance on American claims to exceptionalism and American actions abroad, a 
concern about the context and cause of abuses, that drew on legacies of the 1960s, and that attempted to create a space for politics, precisely by getting people out of prison.

And yet, the historians' account is not wrong. Looking at Amnesty, part of what we have to understand is how a more avowedly political version of human rights, one that emphasized a need for a kind of human rights politics that went beyond humanitarianism and was sensitive to issues of historical wrongdoing and imperialism, could nonetheless have contributed to the historical rise of the bankrupt form of human rights politics that the historians critique. We have to keep in mind, that is, action's uncertainty - not as a matter of differing agendas, competing intentions, but as a lack of control over the story of which one is part, of a mismatch between how one's actions appear to oneself and how they appear in later history. In Amnesty, Danto saw the possibility for a certain form of promise-making, one directed against imperial narratives of progress and directed toward the creation of more open possibilities for politics. He saw Amnesty as part of a story of a resistance to the kinds of abuses exemplified by the US war in Vietnam and by French colonialism, a story not of the gradual progress of the French and American founding principles, nor of the approach of an abstract utopia, but of resistance to existing injustice - a story of activism oriented not around principles of moral witness, but around a dogged effort to get people out of prison. And yet - perhaps because of Amnesty's organizational concern with disavowing such politics, an official impartiality that precluded a public description of the broken promises of history, requiring instead an appeal to an abstract utopian politics - his involvement has become part of a very different story.

\section{B. Arthur Danto and Amnesty International USA}


Moyn claims that the view of human rights as "transcending" politics, a view articulated forcefully by Peter Benenson, a founder of Amnesty International, defined the creation of Amnesty International USA. He writes: "When Columbia University professor Ivan Morris founded Amnesty International USA a few years later, and the Riverside chapter began to meet in Columbia philosopher Arthur Danto's living room on the Upper West Side, the impulse remained the same: 'saving the world one individual at a time."'liv The quotation, Danto's, appears to align with the reduction of politics to the salvation of suffering bodies for which Amnesty is criticized - although it is hard not to read the quip, with its strange mixture of humility and grandiosity, as at least somewhat tongue in cheek. Beyond this, the description is mostly correct: Ivan Morris, a scholar of Japanese literature and a close friend of Danto's, personally and professionally, was heavily involved with Amnesty, both through Amnesty International headquarters in London (for which he conducted several investigations and authored multiple reports) and as a co-founder of Amnesty International USA. ${ }^{\text {lv }}$ The Riverside Group began with Morris as the chapter head; Danto took over in 1975, and the group met in his apartment and others on Manhattan's Riverside Drive. ${ }^{\text {lvi }}$ Danto and Morris were both members of AIUSA's board, and at times on the board's executive committee, Danto from the beginning of 1972 to late $19755^{\text {lvii }}$

Danto left the Amnesty USA board in part because of rules about how many members of one chapter could serve on the board at once, though he also noted that the work of the board was never what he was passionate about: it involved some interesting moments, though also many thankless ones. ${ }^{\text {Iiii }}$ The internal politics were also a source of frustration: Danto wrote to Morris to express his "unease," and a concern with "the zeal with which people propose to throw 
other people overboard," noting "an appetite for unity and fear of disunity which may in the end not over-ride human considerations."

Not surprisingly, Danto's passion lay with the work of the Riverside Group itself. Formed in 1966, with 12 members, Riverside was a particularly successful Amnesty chapter. There was a limit on how many prisoners any individual group could "adopt" at a time; Riverside registered as two groups (numbers 3 and 16) in order to double its quota. From its beginning to the time Danto stepped down as head in 1978, the group adopted 59 prisoners, 46 of whom were released, some more than once (that is, some were adopted, released, re-imprisoned, re-adopted, and re-released). Individual group members would take responsibility for each adopted prisoner, reporting back on the case at the group's regular meetings, which took place often and lasted for hours. ${ }^{1 \mathrm{x}}$ Danto took on many cases over the years, from countries including Czechoslovakia, Argentina, Spain, South Africa, Chile, and Morocco. ${ }^{\text {1xi }}$

Hannah Arendt did some letter-writing as well. On the request of an Amnesty International chapter in Belgium, she wrote to General Augusto Pinochet and others in the Chilean government in November of 1974 to request the release of Luis Vitale and other Chilean historians. She cited her interest as a fellow scholar, writing that without "freedom of speech and thought...no scholarship is conceivable," and suggesting that the cases would be of interest to all scholars. One can assume that, rather than appealing to Pinochet's interest in scholarship, she meant to underscore the potential for publicity. Vitale was released in the weeks following. She also contributed money to Amnesty USA, though appears to have declined an invitation to serve on their National Advisory Council. ${ }^{\text {lxi }}$

In the November 11th, 1972 edition of The New York Times, preserved by Amnesty International USA in their official records, Morris wrote an editorial describing the organization 
and its mission. As he put it: "Prisoners of conscience...exist, to our shame, in almost every country of the world except a few exemplary states like Norway and the Netherlands. ...As long as such men continue to be persecuted and imprisoned, the Universal Declaration of Human Rights remains what it has been until now—a mockery." forth a commitment not to abstract humanity, but to making good on the promise of the UDHR. It also pointedly lists only two countries as exemplary, Norway and the Netherlands - not the United States.

While Amnesty chapters were officially barred from taking positions on their own nation's politics, and from adopting prisoners in their own nations, this did not amount to complete neutrality, as Morris's omission makes clear. Danto and Embree's letter to Kissinger, sent on Columbia letterhead, chided him for his double-talk and reminded him of the importance of securing the release of prisoners. It contains echoes of Amnesty's strategy in its use of letter writing as a tactic, emphasis on publicity, and appeal to principles of humanity and morality. The letter had in fact been discussed during a conversation at the Riverside Group's meeting on January 20, 1975, where it was decided that, alongside other efforts, Danto and Embree would write to Kissinger, "expressing our gratitude concerning his efforts for Chilean prisoners and urging him to do more."

When the US came under criticism for refusing amnesty to Vietnam draft resisters, and for its own political prisoners, Amnesty's American chapters searched for ways to signal their opposition to US practices within their official Amnesty roles. During the board meeting at which amnesty for draft resisters was discussed, Danto suggested that the group reiterate that AIUSA had a policy against taking a position but that the International did have a position, and that they repeat what that position was. Barbara Sproul proposed they might act like a 501(c)(4) 
organization - a concept that seemed obscure and novel at the time - and educate the public on what was going on, even without advocating particular actions. ${ }^{1 \mathrm{xv}}$

It was also suggested at that meeting that inquiries be referred to the American Civil Liberties Union, which was leading a campaign on amnesty for American draft resisters and others. The ACLU campaign included letter writing, Amnesty-style, on the prisoners' behalf, as well as Congressional lobbying and the issuing of public statements. The organization tried to enlist Hannah Arendt's help with this; Arendt does not seem to have signed onto these letters, despite being asked, though she did sign onto other letters seeking the release of political prisoners as part of International PEN and as a member of the executive board of PEN American Center in 1973 and 1974. ${ }^{\text {lxvi }}$ She did also describe herself as a member and "a great admirer" of the ACLU. ${ }^{\text {lxvii }}$

In explaining what motivated him to become involved in Amnesty, Danto describes being in Paris in 1961 and 1962, working on what would become Narration and Knowledge, feeling apprehensive about "terrorism," and seeing "bodies, mostly of Algerians, floating in the Seine" (presumably referring to the October 17, 1961, Paris Massacre, in which French police killed and brutalized protesters, and threw many of their bodies into the river). He writes that the French use of torture in this time became the "source" of the "epidemic of torture throughout the Third World," and that "it was especially because of its antitorture campaign that I became active in Amnesty International."'xviii

Danto carried over additional memories of the 1960s into his political work in the 1970s, particularly his involvement in the protests at Columbia in 1968. He tells how the students, occupying Hamilton Hall, called him at home and asked him to come in and discuss things with them; he said he would be happy to, but only so long as they stopped holding the Dean 
hostage. ${ }^{\text {lxix }} \mathrm{He}$ later served on Columbia's "Tripartite Commission," established by Columbia's president to decide how to handle disciplinary proceedings after the protests. ${ }^{\text {Ixx }}$ There, Danto advocated against harsh punishments for the students; while the students were not granted full amnesty, they were collectively placed on probation and received no further punishment unless that probation was violated (with some individual exceptions). ${ }^{\mathrm{lxxi}}$ Danto himself shared the students' opposition to the war in Vietnam and concerns about the relationship between Columbia and the largely black and Latino neighborhoods surrounding it. He later chaired a committee to review the General Studies program, recommending Columbia create a parallel two-year institute for local residents, with additional advising and flexibility in designing a major, from which students would be able to transfer into the regular four-year general studies program. ${ }^{\text {lxxii }}$ And he shared the students' opposition to a gym Columbia had proposed, and started to build, which would have converted a portion of Morningside Park into campus property, and would have included separate entrances for university affiliates and those not affiliated, most of whom would have been from the surrounding neighborhoods, with the latter entrance on a lower level. . $x x i i i^{\text {. }}$

Danto's personal involvements at Columbia and at Amnesty are similar on several levels. At a substantive level, we see a politics that was opposed to American and French imperial actions, and racial domination in America, and that saw these as connected to other forms of violence abroad. Formally, we also see a politics that was oriented toward enabling other forms of political action, be it student protest or the work of "prisoners of conscience" abroad. His politics also resonate with his own philosophical commitments: an opposition to a teleological history, as though rights just "rolled out" from America and France to the rest of the world, and an opposition to historical positivism, endorsing instead the notion that events take on 
significance over time that the actors involved cannot know. Describing 1968, Danto writes that "it took the students themselves by surprise, not realizing what they had started." He goes on: "I learned what it is like to live in history. It is not knowing how things are going to come out." "lxxiv Historians are not entirely wrong in describing a discourse of human rights that came to prominence in the 1970s and that, for its focus on individual suffering and its alleged nonpartisanship, obscured the political causes of ongoing oppression, emphasizing the salvation of the individual over collective liberation, a commitment to abstract morality over the political activity of mutual promise-making. And yet, in Danto's own work, we can see one attempt, through Amnesty, to undo some of the harms of an imperial past, to create a space for politics in the present, through commitments to show up for people, to advocate for and support them. Even as, at times, he used a moral register to describe his aims, as in his letter to Kissinger, this was not a morality entirely divorced from politics. For Danto, his involvement was not part of an attempt to tell a story of American and French virtue; instead, he was involved in a collaborative effort to confront torture and wrongful imprisonment, understood not as moral evils committed by ill-intentioned individuals but as parts of the legacies of past wrongs, not as aberrations in the path of progress but as outrages that gave the lie to historical teleology. In both his activism and his contemporaneous academic writing, he attempted to forge a way of relating to the past, and to the future, that would enable freedom in the present in a manner premised not on knowledge and control, but on non-sovereignty. And his work helped attend to some of the real impediments to political action, the impediments to freely re-making history: the fact of imprisonment and brutality, the need for financial support.

Amnesty's politics may ultimately have been of a piece with the reclamation of American virtue that Keys diagnoses. And yet we should not take Keys' story as permanently fixed, either. 
Rather than write off Danto's activism, we might see in it an attempt to do what he could, to forge the conditions for action, amid uncertainty. This is not to say that his approach was perfect, that he could not have done more, that other approaches might not have been preferable. But that his story could be part of Amnesty International's story should tell us something, too, about Amnesty: that the idea of human rights motivating at least some people involved with Amnesty could provide the terms for a shared commitment to politics, rather than to an apolitical morality. Such participation could serve as a bulwark against the uncertainties of action, a commitment to continue showing up for distant prisoners, and for one another.

Telling our own histories of human rights, we might think not about continuous legacies, or those legacies' refusal, but rather about the ways in which human rights politics might attempt (or fail to attempt) to re-found earlier promises, avoiding the disavowals that came with them. In telling histories of human rights, we would do well to refuse the dilemma between a romantic emplotment, tracking promises and gradual fulfillments, and a reductive one, dismissing the potential of past efforts in light of what followed. And in refusing such a dilemma, we might better describe the experience of political action, of not knowing how it will all turn out. Attending to the uncertainty of action, and to the ways in which promises to show up for one another might attempt to counteract that uncertainty, we might instead emphasize openness, the possibility of changing the meaning of the past for the present. Told this way, we might understand human rights promises, and claims, neither as the extension or augmentation of earlier promises, of earlier forms of human rights politics, nor as clear departures from what came before. Instead, we might think about how human rights politics can, or can fail to, critique and re-found earlier promises - and can be subject, itself, to critique and re-founding in turn. 
${ }^{\mathrm{i}}$ Correspondence, Organizations, Amnesty International, Hannah Arendt Papers, Manuscript Division, Library of Congress, Washington, D.C.

ii I am grateful to Lydia Goehr and the Danto family for sharing several drafts of this letter from his personal papers. Danto is presumably referring to Bill Moyers' January 16, 1975 interview with Henry Kissinger, on the PBS show "Bill Moyers Journal.” The issue of Chilean prisoners came up in the context of a question about the balance of "morality and pragmatism in foreign policy," and the apparent lack of "humanity" in America's role in the overthrow of the Allende government in Chile. Kissinger said: "And I believe when all the facts are out, it will turn out that a substantial number of the released from Chilean prisons were negotiated by the United States without ever making anything of it, not because we did not believe in these human rights, but because we believed it would facilitate the objective of implementing these human rights if we did not make an issue of it." For a complete transcript, see "Secretary Kissinger Interviewed for Bill Moyers' Journal,” Department of State Bulletin, Vol. LXXII, No. 1859, February 10, $1975,165-178$, especially pages 177-178.

iii Lynn Hunt, Inventing Human Rights: A History (New York and London: W.W. Norton and Company, 2007), 175.

iv Samuel Moyn, The Last Utopia: Human Rights in History (Cambridge and London: Belknap Press of Harvard University Press, 2010), 86-88. Notably, Hunt is using "promise" in the singular, and more abstract, sense, while Moyn speaks of "promises." Even as, at least in some cases, they are both referring to the same historical events of promise-making, Hunt's language contains an ambiguity that already tells us something about her approach: that there is something promising, some potential or cause for hope, built into acts of promise-making. This sense of optimism, that promises somehow project themselves forward in time, already containing the 
seeds of possible futures, is something Moyn explicitly rejects. His emphasis on the agency of later actors comes out more clearly in his essay "On the Nonglobalization of Ideas"; by emphasizing, here, the agency of actors with respect not just to the future, but to the past, I try to push this insight farther. See Samuel Moyn, “On the Nonglobalization of Ideas,” in Global Intellectual History, ed. Samuel Moyn and Andrew Sartori (New York: Columbia University Press, 2013), p. 187-204.

v Though I do not discuss this text at length here, Arendt, in On Revolution, also refers to the American and French declarations as such "promises."

${ }^{\text {vi }}$ My sense of the genre of history here, and the romantic genre in particular, is indebted to David Scott, and in turn as well to Hayden White; see David Scott, Conscripts of Modernity: The Tragedy of Colonial Enlightenment (Durham and London: Duke University Press, 2004).

vii Writing about the relationship between political theory and history, Moyn has called for "a richer meditation on the way that even the highest thought inhabits its social worlds, in relation to which it is simultaneously constituted and constitutive." I agree, but would add that, in attending to its constituted and constitutive aspects, we should also attend to the uncertainty and sense of possibility in efforts by political thinkers and actors to re-imagine their world, to renarrate their own context. That uncertainty about both the past and the future, about the story of which one is part, is part of the relationship between thought and its context. Samuel Moyn, "History and Political Theory: A Difficult Reunion," Theory and Event 19, no. 1, 2016.

viii For this language in Hunt, see, for example, Hunt, Inventing Human Rights, 160.

ix Moyn, “On the Nonglobalization of Ideas,” 190-191.

x Aziz Rana, The Two Faces of American Freedom (Cambridge: Harvard University Press, 2010). 
${ }^{x i}$ Robert Gooding-Williams, In the Shadow of DuBois: Afro-Modern Political Thought in America (Cambridge: Harvard University Press, 2011). See especially chapter 5, "Douglass's Declarations of Independence and Practices of Politics,” 162-209.

xii Paul Gilroy, The Black Atlantic: Modernity and Double Consciousness (Cambridge: Harvard University Press, 1993).

xiii Gooding-Williams, In the Shadow of DuBois, 195.

xiv Mary Ann Glendon, A World Made New: Eleanor Roosevelt and the Universal Declaration of Human Rights (New York: Random House, 2001), xvii. It is worth noting that the romantic emplotments of human rights - the long promise-fulfillment trajectories - occur more often in mass-market history books than in strictly academic ones.

${ }^{x v}$ See Cassin's “La Déclaration Universelle des Droits de l'homme: Discours du Président René Cassin, Délégué de la France, prononcé, à la séance du 9 Décembre 1948, de l'Assemblée Générale des Nations Unis a Paris," Archives Nationales, 382AP/128.

${ }^{x v i}$ National Association for the Advancement of Colored People, An Appeal to the World: A Statement on the Denial of Human Rights to Minorities in the Case of Citizens of Negro Descent in the United States of America and an Appeal to the United Nations for Redress, ed. W.E.B. DuBois (New York: National Association for the Advancement of Colored People, 1947), 2. xvii Gary Wilder, Freedom Time: Negritude, Decolonization, and the Future of the World (Durham and London: Duke University Press, 2015), 163.

xviii See, for a classic example, Bonnie Honig, Political Theory and the Displacement of Politics (Ithaca and London: Cornell University Press, 1993); more recently, Ella Myers, Worldly Ethics: Democratic Politics and Care for the World (Durham and London: Duke University Press, 
2013). For a version of this specific to human rights, see Ayten Gündogdu, Rightlessness in an Age of Rights (New York: Oxford UP, 2015).

xix Hannah Arendt, The Human Condition (Chicago: The University of Chicago Press, 1998), 7. ${ }^{\mathrm{xx}}$ Ibid, 175-177.

xxi Ibid, 220.

xxii Amy Allen, The Power of Feminist Theory: Domination, Resistance, Solidarity (Boulder: Westview Press, 1999), 92-93.

xxiii Arendt, The Human Condition, 180

${ }^{\text {xxiv }}$ Honig, Political Theory and the Displacement of Politics, 84-88.

${ }^{x x v}$ Alan Keenan, Democracy in Question: Democratic Openness in a Time of Political Closure (Stanford: Stanford University Press, 2003), 89, emphasis Keenan's.

${ }^{x x v i}$ Arthur Danto, Narration and Knowledge (New York: Columbia University Press, 2007), 152. xxvii Here, I also have in mind Mark Bradley's discussion of the narration of beginnings and endings, or "ticks" and "tocks," in the history of human rights, and his discussion of Frank Kermode. In those terms, we might talk about the way an actor doesn't know a beginning from an end from a "muddle," and that by focusing on beginnings and endings (and on long versus short history) we miss something of the experience of action in time. Mark Bradley, "American Vernaculars: The United States and the Global Human Rights Imagination,” Diplomatic History 38, no. 1 (January 2014): 1-21. Also see Frank Kermode, The Genesis of Secrecy: On the Interpretation of Narrative (Cambridge, MA: Harvard University Press, 1982), and Frank Kermode, The Sense of an Ending (Oxford: Oxford University Press, 2000). xxviii This is in line with Patchen Markell's reading of Arendt, and particularly his response to Keenan. Markell maps the supposed tension between foundation and freedom onto the alleged 
tension in political theory between rule and rupture, and reads Arendt on "beginning" to argue against treating this as a dilemma, while also explaining why it so often appears that way.

Patchen Markell, “The Rule of the People: Arendt, Archê, and Democracy," American Political Science Review 100 no. 1 (February 2006): 1-14.

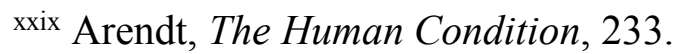

xxx Ibid, 191.

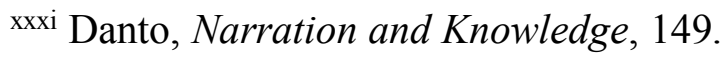

xxxii Arendt, The Human Condition, 192.

xxxiii Danto, "Looking at the Future Looking at the Present as Past," draft manuscript. Arthur Danto Papers, Columbia University, Box 3 Unprocessed, page 7.

xxxiv Danto, Narration and Knowledge, 297. With respect to the problem of "other minds," I take Danto's move here to parallel Stanley Cavell's, his friend and frequent interlocutor. Rather than insist and focus on the unknowability of other minds, or of other periods, treating that as the puzzle to be solved, both authors underscore what this might tell us about our inability to know our own mind, or our own period - that our "own" might be just as "other" as those more obvious others. For Cavell, knowing our own mind is itself a problem of acknowledgement, or of how we find ourselves. As he concludes: "To know you are in pain is to acknowledge it, or to withhold the acknowledgement. - I know your pain the way you do." Stanley Cavell, "Knowing and Acknowledging," Must We Mean What We Say? (Cambridge: Cambridge UP, 2002): 238266.

${ }^{\mathrm{xxxv}}$ Danto, Narration and Knowledge, 294.

xxxvi Ibid, 284.

xxxvii Ibid, 153-155. 
xxxviii Arthur Danto, "Intellectual Autobiography of Arthur C. Danto,” in The Philosophy of Arthur C. Danto, ed. Randall Auxier and Lewis Edwin Hahn (Chicago: Open Court, 2013): 1-70. See 29.

xxxix Hannah Arendt, "Truth and Politics," Between Past and Future, ed. Randall Auxier and Lewis Edwin Hahn (New York: Penguin, 2006): 223-259. The essay is, of course, far more complicated than I have room to elaborate here; notably, she closes by referring to the realm of truth as the realm in which promises might be kept, and in which freedom is possible.

${ }^{\mathrm{xl}}$ Arendt, The Human Condition, 235-236.

xli Ibid, 237.

xlii Note that revising here seems different than "reversing." We might not be able to go back, but we can still undo the relevance of action for the present.

xliii I am drawing here on Stanley Cavell's claims about marriage in general, and what he terms the "comedy of remarriage" in particular, in his Pursuits of Happiness, which I take to be in part a response to J.L. Austin. Stanley Cavell, Pursuits of Happiness: The Hollywood Comedy of Remarriage (Cambridge: Harvard UP, 1994).

xliv Arendt, The Human Condition, 237.

xlv David Scott, Omens of Adversity: Tragedy, Time, Memory, Justice (Durham and London: Duke University Press, 2014), 108-109. xlvi Ibid, 34 and 37.

xlvii See Scott, Conscripts of Modernity. Importantly, Scott is using tragedy, in Omens of Adversity, to describe something about the uncertainty of action, its "disorder" (as he puts it, quoting Raymond Williams, on 35). While the term risks suggesting that the genre of one's story itself is already determined, that something about action's uncertainty already means that things 
will not turn out well, I understand Scott's point to be anything but. While he suggests that action's uncertainty has to do with the inability of actors to direct, through their own intentions, the outcomes of their actions, his emphasis is on the impossibility of overcoming such a condition. Understood this way, his point aligns with Arendt's: that freedom necessarily arises from and within a lack of order and control, rather than (as per George Keenan) from disorder's overcoming. Along these lines, though, I would emphasize that the inability of actors to direct their own actions has less to do with their intentions colliding with those of other people, and so with a conflict of interests or desires, and more to do with the plasticity of the past, and of the future - with not knowing the story of which one is part, with not knowing how it all turns out (Scott, Omens of Adversity; see his chapter 1, "Revolution's Tragic Ends: Temporal Dimensions of Political Action," especially pages 46-48). xlviii Scott, Omens of Adversity, 117. xlix For more on Danto's philosophy of history in the context of postwar historiography debates, and particularly a backlash against Hegel, see Lydia Goehr, “Afterwords: An Introduction to Danto's Philosophies of History and Art," History and Theory 46 (February 2007): 1-28.

${ }^{1}$ Here, I am drawing on Moyn and Keys's accounts, as well as Stephen Hopgood, Keepers of the Flame: Understanding Amnesty International (Ithaca: Cornell UP, 2006). See also “Amnesty International USA"; Ivan I. Morris Papers; Box 29 Folder "Amnesty International - Misc"; Rare Book and Manuscript Library, Columbia University Library. Also see "Suggestions for an American Section of Amnesty International"; November 1965; Amnesty International of the USA, Inc.: National Office Records, Box I.1.1 Folder 1; Rare Book and Manuscript Library, Columbia University Library.

li Moyn, The Last Utopia, 132. 
lii Barbara Keys, Reclaiming American Virtue: The Human Rights Revolution of the 1970s (Cambridge: Harvard University Press, 2014), 201.

liii Mark Bradley, The World Reimagined: Americans and Human Rights in the Twentieth Century (Cambridge: Cambridge University Press, 2016), 198-207.

liv Moyn, The Last Utopia, 132.

${ }^{\text {lv }}$ For more on Morris's role in Amnesty, see Albin Krebs, "Ivan Morris of Columbia is Dead; A Specialist in Oriental Cultures," The New York Times, July 21, 1976, 36. Also see Ivan I. Morris Papers; Boxes 4, 5, 6, 29, and 42; Rare Book and Manuscript Library, Columbia University Library; also Danto 201315.

lvi See "The Riverside Group, Amnesty International USA Group 3/16, 1966-1987”; November 12, 1987; Amnesty International of the USA, Inc.: National Office Records, Box IV.2.2 1 Folder "Riverside Group"; Rare Book and Manuscript Library, Columbia University Library. For Danto's takeover, see Morris' Letter to Martin; February 14, 1974; Ivan I. Morris Papers; Box 4 Folder "Correspondence"; Rare Book and Manuscript Library, Columbia University Library. lvii For records of Danto's joining the board, see "Minutes of the Annual Meeting and the Board of Directors Held March 4, 1972," March 28, 1972; Amnesty International of the USA, Inc.: National Office Records, Box I.1.1 Folder 8; Rare Book and Manuscript Library, Columbia University Library. For Danto's resignation from the board, see Letter from Arthur; Ivan I. Morris Papers; Box 4 Folder "Correspondence"; Rare Book and Manuscript Library, Columbia University Library. For Morris' letter in reply, see Letter to Arthur, October 24, 1975, Ivan I. Morris Papers; Box 4 Folder "Board of Directors"; Rare Book and Manuscript Library, Columbia University Library. For his official resignation, see AIUSA Board of Directors 
Meeting; December 17, 1975; Amnesty International of the USA, Inc.: National Office Records, Box I.1.1 Folder 12; Rare Book and Manuscript Library, Columbia University Library. lviii See, for example, "Meeting of the Board of Directors, February 7, 1974, Minutes"; Ivan I. Morris Papers; Box 4 Folder "Board of Directors - Minutes"; Rare Book and Manuscript Library, Columbia University Library.

lix Letter from Arthur to Ivan; November 21, 1974; Ivan I. Morris Papers; Box 4 Folder "Board of Directors"; Rare Book and Manuscript Library, Columbia University Library (emphasis Danto's). 1x See "The Riverside Group, Amnesty International USA Group 3/16, 1966-1987”; November 12, 1987; Amnesty International of the USA, Inc.: National Office Records, Box IV.2.2 1 Folder "Riverside Group"; Rare Book and Manuscript Library, Columbia University Library. lxi See Ivan I. Morris Papers, Box 5, Folder "Riverside," as well as Amnesty International of the USA, Inc.: National Office Records, Box IV.2.2 1 Folder "Riverside Group." lxii See Correspondence, Organizations, Amnesty International, Hannah Arendt Papers, Manuscript Division, Library of Congress, Washington, D.C.

Correspondence, Organizations, Amnesty International, Hannah Arendt Papers, Manuscript Division, Library of Congress, Washington, D.C. lxiii Clipping in Amnesty International of the USA, Inc.: National Office Records, Box IV.2.2 1 Folder "Riverside Group"; Rare Book and Manuscript Library, Columbia University Library. lxiv See Ivan I. Morris Papers, Box 5, Folder "Riverside," as well as Amnesty International of the USA, Inc.: National Office Records, Box IV.2.2 1 Folder "Riverside Group."

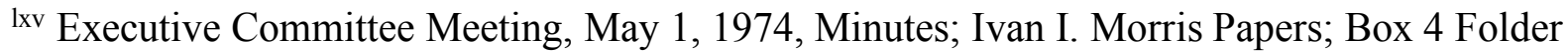
"Executive Committee Minutes"; Rare Book and Manuscript Library, Columbia University 
Library. Danto's opinions on the draft, and on Vietnam, were more complicated than this alone suggests; see, for example, Arthur Danto, "On the Moratorium,” Columbia Spectator, March 12, $1968,4-5$.

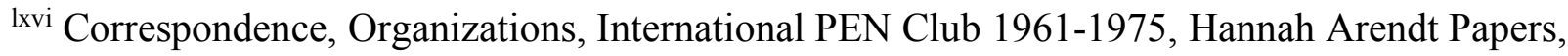
Manuscript Division, Library of Congress, Washington, D.C.

lxvii Correspondence, Organizations, ACLU 1972-1975, Hannah Arendt Papers, Manuscript Division, Library of Congress, Washington, D.C.

lxviii Danto, Intellectual Autobiography, 17.

1xix He said he opposed the holding of the Dean on "Kantian grounds," because it involved using another person as a means. The students replied the dean was not hostage, but was free to go adding that they were also free to beat him up if he tried (Danto 2013 33-34).

lxx Statement by President Grayson Kirk; April 29, 1968; University Protest and Activism Collection, Box IV.4 Folder 27; University Archives, Rare Book and Manuscript Library, Columbia University Library.

Ixxi Initial Recommendations of the Columbia University Joint Committee on Disciplinary Affairs; May 9, 1968; and Joint Committee on Disciplinary Affairs, May 13, 1968; University Protest and Activism Collection, Box IV.7 Folder 1; University Archives, Rare Book and Manuscript Library, Columbia University Library. Also see Statement to the Members of the Faculty and Students of Columbia University from Acting President Andrew Cordier; September 11, 1968; University Protest and Activism Collection, Box IV.7 Folder 1; University Archives, Rare Book and Manuscript Library, Columbia University Library. 
lxxii See Curt Mechling, "GS Re-Evaluating Place in University,” Columbia Spectator, March 10, 1969, 1, and Juris Kaza, “Report Proposes Dual Role for GS,” Columbia Spectator, May 6, 1969, 1. lxxiii Describing the controversy, Danto emphasizes that the political significance of the gym changed over time. He writes: "The gym was a classic example of an idea that had seemed good at one moment but bad at another," noting that, in 1961, Jane Jacobs had praised the plan for its inclusion of the community, "But in 1968, the two-tiered architecture seemed an intolerable symbol of segregation to everyone who thought about it." Arthur Danto, "Before the Revolution: Arthur C. Danto on the 1968 Revolt at Columbia University," Artforum International 46, no. 9 (May 2008), 95. lxxiv Danto, Intellectual Autobiography, 32-34. 